\title{
Performance management systems' stability: Unfolding the human factor - A case from the Italian public sector
}

\author{
Laura Maran $^{\mathrm{a}, *}$, Enrico Bracci ${ }^{\mathrm{b}}$, Robert Inglis ${ }^{\mathrm{a}}$ \\ ${ }^{\text {a }}$ School of Accounting, College of Business, RMIT University, 445, Swanston Street, Melbourne, 3000 VIC, Australia \\ ${ }^{\mathrm{b}}$ Department of Economics and Management, University of Ferrara, Via Voltapaletto, 11, 44121 Ferrara, Italy
}

\section{A R T I C L E I N F O}

\section{Keywords:}

Performance management

Italian public sector

Balanced scorecard

Structuration theory

Factors of change and stability

\begin{abstract}
A B S T R A C T
The aim of this study is to examine the institutional context during the emergence of New Public Management (NPM), which created pressure on public sector organizations to implement performance management systems (PMSs), such as the balanced scorecard (BSC). Drawing on Granlund's framework (2001) and Giddens' (1979) structuration theory, we engage insights from a longitudinal case study of an Italian local authority to show how managers exercise agency before the mandated implementation of the BSC. This analysis suggests a re-interpretation of Granlund's (2001) factors of inertia (human, institutional and economic) in terms of balance among the three factors, and inclusion of a historic and culturally specific perspective. The findings also encourage a broader consideration of the agency of managers in a public entity before the design and enhancement of a NPM tool.
\end{abstract}

\section{Introduction}

The reasons, processes and outcomes relating to changes to accounting in the public sector have been a near constant topic of inquiry since at least the 1990s (Broadbent \& Guthrie, 2008; Cooper, Ezzamel, \& Qu, 2017; Järvenpää \& Länsiluoto, 2016). Many researchers associate these changes with reforms inspired by New Public Management (NPM), which introduced management accounting and control practices from the private sector to enhance efficiency, effectiveness and public accountability (Bracci, Maran, \& Inglis, 2017; Dunleavy \& Hood, 1994; English \& Skellern, 2005; Hood, 1991; Lapsley, 2008). The literature on changes to management accounting has emerged in different and partly overlapping clusters (Lukka, 2007). For instance, these changes to accounting practices have been studied from a number of perspectives, including environmental contingencies, change management approaches (e.g. Carlin \& Guthrie, 2003; Christensen \& Lægreid, 2007; Pollitt \& Bouckaert, 2004; Scapens \& Roberts, 1993), and institutional-based views (e.g. Dacin, Goodstein, \& Scott, 2002; Ho, 2011; Scapens, 2006; Ter Bogt, 2008). However, very few management accounting studies (Granlund \& Lukka, 1998; Granlund, 2001; Lukka, 2007) pay explicit attention to the flipside of change, namely stability. Siti-Nabiha and Scapens (2005) show that stability and change are not necessarily contradictory or opposing forces, but can coexist in an evolutionary process (see also Aroles \& McLean, 2016). Furthermore, studies of management accounting change tend to examine whether and why a certain management accounting technology was implemented, focusing on change within formal systems (Arnaboldi, Lapsley, \& Steccolini, 2015; Cooper \& Kaplan, 1988; Kaplan \& Norton, 1996). The informal domain of participants' actions and their everyday behavior in the organization has received much less attention (Aroles \& McLean, 2016; Lukka, 2007).

This study draws on Englund, Gerdin, and Burns's (2011) review of the empirical accounting literature on stability (p. 501) to

\footnotetext{
* Corresponding author.

E-mail addresses: laura.maran@rmit.edu.au (L. Maran), enrico.bracci@unife.it (E. Bracci), robert.inglis@rmit.edu.au (R. Inglis).
} 
provide an account of how macro (external pressures) and micro (organizational) factors can explain the preference for stability over a change. Our primary research question is: how and why do factors at the macro (external pressures) and micro (organizational) levels influence the preference for stability over a change? Diverse studies have conceived organizational actors' behavior to be a consequence of external pressures. This acknowledges a continuous relationship between external and organizational levels that is often deterministic or "taken for granted" (Englund et al., 2011, p. 501; Giddens, 1984, p. 60).

In our study, the analysis of the external context is especially appropriate given the political nature and implications of regulatory change in the Italian public sector. These external pressures are also subject to the reflexivity of organizational agents and their conscious decisions, which are interconnected with the micro-organizational level (Englund \& Gerdin, 2014; Englund et al., 2011; Greenhalgh \& Stones, 2010; Liguori \& Steccolini, 2012; Pina, Torres, \& Yetano, 2009).

We draw on Granlund's (2001) work, which bridges institutional theory and structuration theory (Giddens, 1979, 1984) with specific reference to "knowledgeable agency" (see also Englund \& Gerdin, 2014). Granlund (2001) addresses some of the perceived limitations of institutional-based theory (i.e. the "taken-for-grantedness") in relation to organizational change or stability (Cloutier \& Langley, 2013; Gurd, 2008; Humphrey \& Scapens, 1996). His seminal work offers the opportunity to focus more on the micropractices of organizational actors - the human element in explaining change and stability. We use this concept to argue that stability implies actions on the part of organizational actors, even if these are not reflected in the outcome. In other words, even though no overall change is observed, people in organizations still undertake actions to maintain or modify the status quo - and it is an interrogation of these actions that forms the basis of our case study.

To address our research question, we conduct an analysis of how the implementation of a performance management system (PMS) in a public sector organization triggered a broader reflection on the substance, politics and context of actions (Dawson, 1996; Pettigrew, 1997) that favored stability over change. PMSs represent a central piece of the overall process of public sector reforms that affect and are affected by the public managers' action (Arnaboldi et al., 2015). In line with many of the management accounting change studies (Lukka, 2007; Scapens \& Roberts, 1993), we adopt a longitudinal case study approach over a three-year period, from 2008 to 2010.

This study responds to the call for further exploration of the origins of stability and change in PMSs (Englund et al., 2011) by expanding Granlund's (2001) work in three ways. First, we provide a systematic interpretation of Granlund's (2001) findings, broadly referring to economic, institutional and human/individual dimensions, which we use to frame our work. Second, we offer a longitudinal evaluation of the interrelations among these dimensions in a local authority, beyond Anglo-Saxon contexts. The public sector context is multi-functional, with institutions that may not merely maximize a simple set of goals, but must compromise between conflicting objectives and values (Llewellyn \& Tappin, 2003). Ambiguous and inconsistent goals are inherent characteristics of the public sector, therefore political and administrative leaders are permanently confronted by tensions and dilemmas to which there is no simple solution. Our analysis of how the three dimensions interact in changing or maintaining the stability of the current structure has relevant policy and practical implications.

Third, we expand Granlund's (2001) work by providing a specific account of macro-level pressures and micro-level (case) practices, actions and behavior, and proposing a continuous dialectic comparison between the two levels of analysis. Our means of obtaining accounts of external pressures for change differs from studies that interpret the perceptions of organizational actors (e.g. Stones, 2005), since we examine the longitudinal economic (data) situation of Italian public administration, and the laws and regulations requiring the PMS implementation. Moreover, in analyzing the micro-level practices, we offer a detailed analysis of how agents use their knowledge and practices to reproduce and/or make decisions to influence their everyday actions, and how this affects the organization. Our perspective emphasizes the link between the practices of variously situated agents and the production and reproduction of institutionalized systems. We develop empirical insights regarding the gap between actor microprocesses and external (macro-level) pressures.

The remainder of the paper is presented as follows: in the next section we explore the work of Granlund (2001) as informed by Giddens' (1979) structuration theory and institutional theory (Powell \& Di Maggio, 1991) to classify factors affecting new accounting system development (or intentions) within an organization. The third section introduces the research design. In the fourth section, we present our analysis and interpretation of the context of change through Granlund's (2001) systematization, and in the fifth section we show the findings of the case organization. The sixth section provides a discussion, followed by some concluding thoughts on the managerial and theoretical implications of our case findings and suggestions for future research.

\section{Theoretical orientation}

Granlund (2001) offers a framework, based on institutional theory (Powell \& Di Maggio, 1991) but also inspired by Giddens' theory of structuration $(1979,1984)$, to explain the failed application of an activity-based costing system on a private for-profit organization. Granlund's (2001) framework borrows the idea of "knowledgeable agents" from Giddens (1979) to show the relevance of the human/individual factor in processes of management accounting change. Recognizing human agency is the main element of distinction with respect to institutional isomorphism (Granlund \& Lukka, 1998), in which the concepts of economic and institutional factors are embedded. In his work, Granlund (2001) provides a detailed description of the case organization followed by a discussion and analysis of the findings of accounting system development within a framework of economic, institutional and human factors. While Granlund (2001) flags the importance of understanding the connections between the factors (p. 157), he does not elaborate on these, nor explore the macro and micro-level linkages.

Englund and Gerdin (2014) use a combination of institutional theory and structuration theory to overcome the limitations of institutional theory, and to address the non-deterministic character of day-to-day activity (see Burns \& Scapens, 2000; Coad \& Cullen, 
2006; Dillard, Rigsby, \& Goodman, 2004; van der Steen, 2009). In addition, van der Steen (2009) and Englund and Gerdin (2008) state that an institutional perspective supports claims of continuity and stability in organizations, but is insufficient to explain why and how organizations embrace continuity and stability when pressured to change. According to Hallet and Ventresca (2006; see also Creed, Scully, \& Austin, 2002), too often institutional theory, which treats institutions as symbolic systems that order reality, has been adopted unquestioningly to understand the persistence or change of institutions and institutional practices.

In the institutional paradigm, stability seems to be connected with a routinization of practices (Burns \& Scapens, 2000; Powell \& Di Maggio, 1991), where individuals or organizational actors largely disappear behind "more or less tacit and taken-for-granted schemas of action that they have developed through past interactions" (Emirbayer \& Mische, 1998, p. 975). In this context, SitiNabiha and Scapens (2005) argue that the main issue with institutional theory and isomorphism is that institutions are tacitly accepted as "the way things are done" (p. 46). According to Lounsbury (2008) and Lawrence, Suddaby, and Leca (2011), this perspective is too rigid and deterministic, and it lacks a notion of institutional rationality as the a product of organizational actors (Giddens, 1979).

Giddens (1979) proposes that structure and agency are a mutually constitutive duality. In structuration theory, knowledgeable agents are to a large extent "reflexive", in that they pause, reflect and make conscious choices about their behavior (Macintosh \& Scapens, 1990). In this way, structuration theory provides a strong background for institutionalization, as conceived by Barley and Tolbert (1997): a continuous process whose operation can be observed only through time, and where individual actors' interactions are bound by existing organizational structures, but are also the means through which structures are reproduced. 'Institutionalized practices' may be taken as given for a particular research study in institutional theory, but they are themselves reproduced through the actions of human agents under the lenses of structuration theory (Macintosh \& Scapens, 1990). Structures are, therefore, sustained by their ongoing reproduction by social actors, but can be changed. Individuals are thus seen as possessing the capability to transform structures, using their knowledge and agency. Parker (2006), Edwards (2006) and Stones (2005) take the view that while Giddens $(1979,1984,1987)$ offered the notion of unlimited ability of actors to respond to institutional pressures, the notion of external structures and their influence on actors required further development.

In this context, the kind of rationality embraced by knowledgeable agents refers to broader cultural beliefs and rules that structure cognition and guide decision making, without involving their specific perception of the external pressures. These considerations provide the basis for a more penetrating examination of actors and their micro-practices (Lawrence et al., 2011; Lounsbury, 2008).

Therefore, Lounsbury (2008) and Garud, Hardy, and Maguire (2007) suggest an important opportunity for theoretical development and empirical insight in the gap between actor micro-processes and external (macro-level) pressures. While the presence of accounting change (or stability) seems from a distance to be institutional isomorphism, it may in fact, when observed from a micro perspective, be the result of active agency. Structuration theory explicitly focuses on the dynamics by which institutions are reproduced and altered, and the role played by individual actors (Barley \& Tolbert, 1997; Scapens, 1994). In Lounsbury's (2008) view, Giddens' (1979) argument allows us to look at institutions as the outcome of agents who are not simply accomplices to social processes, but have a reflective capacity (or appreciative viewpoint) to consciously engage in institutional work (see also Heclo, 2008; Jack \& Kholeif, 2008). If "practices are the negotiated product of agency" (Whittington, 2011, p. 185), the stability of past systems can be interpreted as the momentum carried forward as individuals engage with a change within a frame of reference associated with previous practices and within a set of external (macro) pressures (Aroles \& McLean, 2016; Boudreau \& Robey, 2005; Dechow \& Mouritsen, 2005; Orlikowski, 2000; Quattrone \& Hopper, 2005; van der Steen, 2009).

\subsection{Accounting change and stability: Granlund's (2001) model}

Granlund (2001) inductively classifies factors that affect the implementation of management accounting change projects, and that explain the stability of accounting systems. These factors include values, norms, beliefs and ways of acting within organizations (see Granlund \& Lukka, 1998). His analysis is presented and discussed as pros (i.e. pro-change) and cons (i.e. pro-stability) of the abovementioned accounting system development within the case organization, using a systematization of economic (functional), institutional and individual (human) factors. As shown in Table 1, we interpret and expand Granlund's (2001) systematization to both macro and micro levels of analysis.

Economic factors include economic fluctuations (for instance global or regional recessions, see Chan, Gup, \& Pan, 1997; Chandury \& Lee, 1997), the availability and role of information and production technologies to support the movement towards increasing knowledge, services and goods (Archibugi and Michie, 1997) and competition (Abernathy, Clark, \& Kantrow, 1981). For instance, Granlund and Lukka (1998) suggest that the adoption of multidimensional (including financial and non-financial measures) PMSs

\section{Table 1}

Factors and elements affecting stability.

Source: Elaboration from Granlund (2001), pp. 152-161

\begin{tabular}{ll}
\hline Factors & Elements \\
\hline Economic & - Economic fluctuations, availability of information and production technologies \\
Institutional (functional) & - Enforcement of regulative aspects (coercive pressures) \\
& - Professionalization (normative pressures) \\
& - Embracement of the most prevalent or successful alternatives or patterns (mimetic processes) \\
Individual (human) & - Specific conduct/action of the organizational actors involved in the process of "making sense" of the required change
\end{tabular}


such as the balanced score card (BSC) (see Kaplan \& Norton, 1992, 1996 and 2001) are the globalized result of those economic pressures. Beaubien (2012), Dechow and Mouritsen (2005) argue that control cannot be studied without examining technology (i.e. information technology), which therefore should be considered among the economic factors.

Institutional (or functional) factors include a set of issues that deal with Granlund and Lukka's (1998) recognition of coercive, normative and mimetic processes. Coercive pressures refer to the enforcement of regulative aspects, for instance, the mandate of transnational institutions such as compliance towards European Union regulations, international harmonization of management practices, or even formal and informal initiatives of homogenization from the headquarters or parent companies. Normative pressures (Di Maggio \& Powell, 1983; Scott, 1995) concern the professionalization (university education and professional networks such as national professional associations or national and corporate culture) of management and accountants. Mimetic processes mainly refer to embracing the most prevalent or successful alternatives or patterns in order to ensure the organizational reality is congruent with the frames of social behavior (O'Neill, Pouder, \& Buchholtz, 1998).

Granlund (2001) adds to economic and institutional factors the category of "human (individual)" factors referring to specific conduct or action of the organizational agents involved in the process of "making sense" of the required change. For instance, he lists factors such as a deliberate "delaying game" (nothing being implemented by the deadline), personal skills, prior knowledge in an area of development, flexibility and inclination towards change or resistance and managerial support. According to Granlund (2001), human factors have been largely overlooked and poorly understood, so he points out a concrete need for more analysis of the complexities that underlie requested changes in organizations.

While the human factor represents the main finding and contribution of Granlund's (2001) framework, in this paper the three factors affecting stability (Table 1) are considered as equally important in explaining the tensions between change and stability in organization, and their interactions need to be considered (Granlund, 2001).

\section{Research design}

In this study, we use Granlund's (2001) work to inform but not limit the analysis of the context of change (the implementation of a PMS, see Pettigrew, 1997, and Dawson, 1996) and the organizational agents' reaction (see Broadbent, 1992; Ventresca \& Mohr, 2002). In so doing, we attempt to connect a macro analysis of the political and social context with the micro analysis of the case organization. We did not actively seek to examine how boundaries between the internal and the external structures (macro-level) might be drawn by the agents at the micro-level as suggested by Jack and Kholeif (2008), but we remained open to the potential emergence of such phenomena.

The research design commences with an analysis of the external pressures to implement PMSs in the Italian local government sector. Broader contextual analysis (Ritchie \& Spencer, 1994) includes documenting and reviewing the evolution of the main statutory and NPM reforms undertaken from 1990 onwards. This is especially appropriate given the political nature of the required changes. The use of Granlund's (2001) factors is extended to the role of the "human/individual" factor.

The study then turns to a longitudinal case study of an Italian local authority (see also McLaren, Appleyard, \& Mitchell, 2016), which provides a range of public services including maintenance of infrastructure and roads, provision of social services, primary education, and cultural events (theatre, music, and exhibitions). Fig. 1 provides a timeline of the relevant phases of the development of a PMS within the case organization (2008-2010), matched with the NPM reforms of the period that required the implementation of PMSs. The longitudinal study identifies three phases: design, implementation and (mis)alignment.

During the design phase, the general manager of the case organization decided to implement the BSC as a PMS, in response to political and legal pressure to reform. The BSC was chosen because it is a sequential model, and similar to Italian law prescriptions on PMSs (see section 4.2). The general manager also identified a timeline (see Fig. 1) and a steering group of managers, believing that with adequate training in the BSC, they would champion its implementation. Our research began in January 2008, after the general manager's decision. As per Kaplan and Norton (1992, 1996 and 2001), we considered the design phase concluded when the strategic map of the case was set up. We designated 2009 the implementation phase, since the steering group was charged with populating the four dimensions of the BSC (learning and growth, internal processes, community and financial) from the strategic map.

\begin{tabular}{|c|c|c|c|c|}
\hline \multirow[t]{3}{*}{$\begin{array}{l}\text { Main relevant } \\
\text { NPM reforms }\end{array}$} & $\begin{array}{l}\text { d.lgs. } 286 / 99 \text { and } \\
\text { d.lgs 298/99 }\end{array}$ & \multicolumn{3}{|c|}{$\begin{array}{l}\text { l. } 15 / 09 \\
\text { d.lgs. } 150 / 09 \text { and } \\
\text { subsequent regulation }\end{array}$} \\
\hline & 1999 & 2008 & 2009 & 2010 \\
\hline & $\begin{array}{l}\text { Relevant phases } \\
\text { in the case study }\end{array}$ & $\begin{array}{l}\text { Design phase } \\
\text { - } \quad \text { BSC steering } \\
\text { group created } \\
\text { - Strategic map } \\
\text { - Managers } \\
\quad \text { training }\end{array}$ & $\begin{array}{l}\text { Implementation } \\
\text { phase } \\
\text { - } \quad \text { Alignment with } \\
\quad \text { annualobjectives } \\
\text { - KPI selection } \\
\text { - } \quad \text { Failed budget } \\
\quad \text { alignment }\end{array}$ & $\begin{array}{l}\text { Alignment phase } \\
\text { - Revised strategic map } \\
\text { - Failed alignment with } \\
\text { performance } \\
\text { assessment } \\
\text { - Failed alignment with } \\
\quad \text { information system }\end{array}$ \\
\hline
\end{tabular}

Fig. 1. Case study timeline and relevant reforms. 
Table 2

Interviews conducted from 2008 to 2010 in the case organization.

\begin{tabular}{|c|c|c|c|c|}
\hline Interviewee & 2008 & 2009 & 2010 & Total \\
\hline General manager & 1 & 1 & 1 & 3 \\
\hline Administration and finance manager & & 1 & 1 & 2 \\
\hline - Service manager of planning and control & 1 & & & 1 \\
\hline - Service manager of human resources & 1 & & & 1 \\
\hline Manager of the infrastructures department & 1 & 1 & 1 & 3 \\
\hline - Service manager of urban planning & & 1 & & 1 \\
\hline Manager of the welfare department & 1 & & & 1 \\
\hline - Service manager of the cultural activities & & 1 & 1 & 1 \\
\hline - Service manager of the youth and sport activities & & 1 & & 1 \\
\hline - Service manager of the theatrical activities & & & & 1 \\
\hline Total & & & & 15 \\
\hline
\end{tabular}

During the implementation phase in 2010, the steering group attempted to select key performance indicators. It became clear that their main interest was to align the BSC with the yearly financial budget, instead of fundamental operational processes. To investigate this process, we sought to understand the experiences of managers - their ways of thinking and acting - involved in the BSC design (2008), the first implementation attempt (2009) and the final (mis)alignment within the organization (2010) (for more detailed discussion of the specificities of the BSC and process of implementation see Bracci et al., 2017).

Data from the case study were gathered through semi-structured interviews (Table 2), participant observation and document analysis. The interviews lasted on average one hour; 10 of them were taped and transcribed. Five interviewees refused to be tape recorded, so we took detailed notes instead. As shown in Table 2, interviewees coming from the same department were interviewed in each phase of the BSC project (design, implementation and alignment), to gather the views (and/or changes of view) of the department (and related services) for the duration of the project. The interview process started with some general questions related to how the interviewee perceived their role within the organization, their specific view on the advancement of the BSC project, and their reasoning on how and why the BSC project was advancing/not advancing throughout the planned phases. We allowed for a freeflowing conversation (Qu \& Dumay, 2011) following these general questions. More specific questions were prompted by interviewees' responses. These included describing the challenging tasks of the role within the organization, and perceptions of how the BSC project influences or was influenced by the functioning of the department/service. The organization granted full access to documents and internal filing systems. Documentary evidence included the financial budget, balance sheet, responsibility-center budget (called Piano Esecutivo di Gestione, or PEG), reorganization plans, agreements about the level of social services to provide (quantity and quality), and general reports used by the departmental and service managers of the local authority and the political program of the mayor as political authority of the local government.

The analysis comprises a detailed account of the local authority's background (i.e. its structure and relationship between management and political organs), and final results on the implementation of the BSC. The case is examined and organized around Granlund's (2001) forces (i.e. economic, institutional and human/individual) to interpret the organizational response in terms of change or stability.

\section{Public sector reforms in Italy: a contextual analysis}

The current structure and functions of the Italian public sector (central, regional and local levels) are the result of a series of historical processes and reforms, starting in 1865, during the Savoy monarchy. In this study, we identify the pressures that the most recent public sector reforms have had on PMS implementation, and analyze the regulative interventions that affect the local authorities and their management, as systematized by scholars of Italian administrative law (Bassanini, 2000; Cassese, 2010; Ginsborg, 2001; Nocera, 2001).

\subsection{Economic forces}

Economic data for Italian public sector finance are publicly available from 1946. Giannino (2011) highlights the ballooning of Italian public debt in the 1980s and early 1990s, as confirmed by Bank of Italy data (Fig. 2). Increases in public debt and spending are one of the causes of the global emergence of NPM (see Dacin et al., 2002; Dunleavy \& Hood, 1994; English \& Skellern, 2005; Granlund \& Lukka, 1998; Hood, 1991). According to Guthrie, Parker, and English (2003) and Richard (2004), governments have reinforced their commitment to implementing NPM by pledging to contain and eliminate public debt.

Despite the reported increase of public debt as a globalized pattern, the Italian situation represents economic pressure to make the Italian public sector more effective, efficient and accountable (Granlund, 2001). From the reports on "public debt with respect to GDP" from 1861 to 2015 (Report of Italian Treasury, 1999; \#38 and \#41, Report of the Bank of Italy, 2008; 2011; Statistics on Italy, from Il Sole 24 Ore, 9 January 2016), it is evident that the main issue for Italy since the 1980s has been that public debt has grown faster than GDP (Fig. 2). The 1992 Maastricht treaty and the adoption of the euro currency across many European countries in 2002 increased the pressure on Italian governments to comply with EU requirements in terms of both deficit to GDP and gross debt to GDP.

The stability pact forced Italian local governments to cope with spending limits, and reduced their scope to recruit or even 


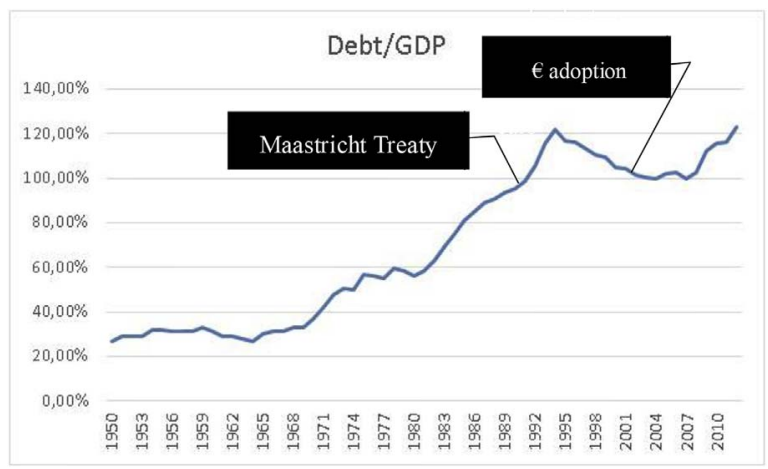

Fig. 2. Italian public debt, in percentage of the yearly GDP.

Source: Bank of Italy statistics (2011).

maintain local public sector employment. Fig. 2 shows that after the peak in 1994 (121\%), the debt/GDP ratio declined constantly down to $99-100 \%$. In the aftermath of the global financial crisis in 2008, the austerity policies implemented in Europe created even greater attention to public finance and levels of efficiency and effectiveness (Bracci, Humphrey, Moll, \& Steccolini, 2015). According to Arnaboldi, Lapsley, and Dal Molin (2016) the European Commission's concern for the health of Italian government finance led to continuous pressure to reform the functioning of public administration, paying particular attention to the efficiency of the system.

\subsection{Institutional forces}

The public sector in Italy was founded after the unification (17 March 1861, with law 4671) under the Savoy royal family, who also established a parliament and government. The Italian public sector was inspired by the bureaucratic administration of the Duchy of Savoy, which was highly regarded during the Napoleonic centralization of France (see Cassese \& Melis, 1990; Randeraad, 1993; Ruffilli, 1989). The monarchy ended in 1945 and the new Republican Italian public sector was involved in three main periods of reform: the first started after World War II and under the new Republic, the second in the 1970s, and the last in the 1990s.

The first reforms were introduced under the Constitution (1945) to further its prescribed articulation of the administrative system in three levels: central, regional and local, with different attributions and roles. The second reforms, in the late 1970s (Laws from 1975 to 1977), tried to enhance the decentralization of the public administration (PA) and to ensure the transparency of political action through the foundation of independent authorities. In 1979, the Minister of State, Massimo Severo Giannini, reported to the parliament the critical conditions of public organizations, stating "the situation of serious malfunctioning of public administration [which] globally taken raises for many areas distressing worries about ungovernability" (Giannini, 1979; p. 5). For some authors, the report was the first attempt to pose the efficiency and managerial problem, years before the advent of NPM (Arnaboldi et al., 2016). However, it was not until the 1990s that a clear goal was established to reform the PA, inspired by the NPM criteria of efficiency, effectiveness and economic accountability (see also Arnaboldi et al., 2016). For instance, art. 51 co. 1 Law 142/1990 reads: "the Local Authorities and the Provinces discipline with their regulations the organizations of offices and services, according to the criteria of autonomy, functionality, economic accountability, management control, expertise and responsibility".

The main laws and decrees of the 1990s (e.g. law 142/1990; law 241/1992, Decree law 77/1995, law 20/1994) attempted to reform the obsolete, complicated and inefficient public system (e.g. no organic reforms had been carried out since 1865), and the need for compliance with European integration. The increasing dynamism of the private social services and manufacturing sectors also contributed to pressure for accelerating the decentralization of public functions to the local level of government, and/or to outsource services to for-profit organizations.

Different laws in the 1990s (for instance, law 81/1993, law 20/1994, law 265/1999, decree law 286/1999 and decree law 298/ 1999) also aimed to introduce control systems within the public sector, at different levels of government. Law $29 / 1993$ explicitly referred to public sector modernization and the adoption of an NPM paradigm (where NPM was inspired from a translation of empirical experiences in the US: Bassanini, 2000). Decree law 286/1999 made compulsory the introduction of a new internal control office responsible for implementing strategic control, managerial control, performance appraisal and legal control. Meanwhile, decree law 298/1999 recommended the use of performance indicators, reflecting quality standards for public services and benchmarks to assess the performance of public administration.

This third wave of reforms lasted almost a decade until the promulgation of Brunetta's decrees (law 15/2009 and decree law 150/ 2009), which operated under the reformed Constitution (from 2001) that framed an increase in autonomy, responsibility and attribution to the local government instead of the central level. Law 15/2009 and decree law 150/1999, in particular, made it compulsory for public organizations to introduce PMSs through the publication of a three-year performance plan. One government document (CIVIT 98/2010) appeared to suggest the BSC as an example PMS to be implemented. The third wave of reform was interrupted by the dismissal of the government coalition and strong government opposition that continues to exist today (see also Arnaboldi et al., 2016).

Granlund (2001) links the processes of stability to the continuity of practices over time, showing that sudden changes in the 
environment (such as the government coalition for the public sector) could lead to organizational change (or stability) depending on their interrelations with the earlier organizational practices.

\subsection{Individual/human forces}

The individual/human role was implied only in the last reforms (from 1990s onwards), when the role of public managers was strictly coupled with the principles of responsibility and accountability towards the use of public funds and the provision of public services (see also decree law 487/1994; decree law 165/2001 and decree law 150/2009; law 92/2012). Before that period, public managers were mere executors. They responded primarily in terms of hierarchical accountability towards the government. According to Smith (1997) and Santoro (2014), from the Italian unification (1861) to the 1990s, the public sector has had an occupational function to sustain levels of employment and salaries, especially in the most economically depressed regions of southern Italy. Therefore, a salient trait of public sector managers has been their hierarchical and disciplinary subordination, which has only very recently evolved towards a broader responsibility for the use of public resources and the provision of quality public services.

Despite the move to adopt PMS tools (decree law 150/2009), the specific nature/form of the PMS (e.g. BSC methodologies) was not explicitly determined by the law. Thus the choice of the most relevant PMS tools and their implementation was (and still is) considered an autonomous choice of the general manager, on the basis of his/her competence and managerial skills, with an assumed proactive motivation towards the change.

The decree law 150/2009 (art. 4, co. 2) states:

[T] the cycle of performance management is articulated in the following steps: a. identification of the objectives, results and indicators, b. linking between objectives and (financial) resources to be allocated, c. monitoring, d. measurement and evaluation of the organizational and individual performance, d. use of rewards systems to appraise the merit, e. reporting of the results to the political organs, the higher public administration levels, the independent Authorities and Agencies, the citizens, and all service users.

The decree assumes the ability of the general manager to set up objectives and resources on a logical and linear path that involves the whole organization in implementing the change. This reflects a very rational approach to PMSs.

In summary, Italian public sector reforms are complex politically, legally and socially, and constantly evolving with changes to the relationships between, and accountability of, various local authorities and an increasing range of stakeholders. Even though the last reforms demonstrate a strong direction towards change, they are implemented over a calcified system of public sector apparatuses for which the principles of functioning were established centuries before, and which did not see any systemic intervention for 131 years between 1861 and 1992. This is the context of the changes that have emerged in the last two decades, and which we categorize using Granlund's (2001) framework for stability and change (see Table 3).

\section{The case of a local authority: analysis and interpretation}

As the organizational chart of our case study shows (Fig. 3), only the general manager formally reported to the mayor and executive councillors of the local authority. The number of executive councillors partially reflected the internal substructure (service managers) of the organization. ${ }^{1}$ The definition of those services depended on the mayor's political program and political coalition at the time. The town council is a political organ elected by the citizens. It represented both majority and minority parties, but by law it could not have a direct influence over or links with the local authority's organizational structure.

The general manager began the process of designing and implementing the BSC in 2008, with the creation of a steering group, initially composed of the general manager and the three departmental managers depicted in Fig. 3. The steering group was in charge of the formalization and description of the main goals of the local authority, according to the mayor's political program and areas of responsibility. In doing that, they had to take into account the theoretical BSC requirement (Kaplan \& Norton, 1992; 1996 and 2001) of making explicit the strategic priorities and the cause-effect relationship between the organization and its environment.

The organizational chart of the local authority (Fig. 3, within the dashed box) includes three main departments: administration and finance, infrastructure and welfare. Each department comprises a number of subunit service providers, for instance, the department of welfare includes the cultural activities (such as museums, archives, theatre, exhibitions, tourism), policies for young people and European cooperation, social services and sport. Due to these detailed activities, there is an informal direct accountability between some services and the executive council member of reference. The original steering group soon involved the service managers to identify a number of strategic priorities according to the mayor's political program (i.e. "maintenance of and lifestyle in town; mobility improvement; sustainable development; quality of care, and culture and efficiency"), as this was an unavoidable commitment towards the mayor and the political party he represented.

The departmental managers then examined their specific areas of responsibility to identify relevant strategic objectives that related to them and to their service managers. Whereas this design phase seemed unproblematic, the subsequent implementation

\footnotetext{
${ }^{1}$ In the period under analysis, the composition of the town council was as follows: mayor (president of the town council): security, general affairs, public contests and farming out, assistance to families, pre-school policies, economic participations; vice-mayor: human resources, culture, tourism and policies for young people; member 1: town planning; member 2: accounting, planning and control systems, balance sheet; member 3: policies regarding commercial and manufacturing activities, professional training; member 4: administrative decentralization, relationships with the citizens, sport; member 5: infrastructures and local traffic; member 6: social services, healthcare services, immigration; member 7: environmental management and international relationships.
} 
Table 3

Forces influencing the change.

\begin{tabular}{ll}
\hline Forces & Change \\
\hline \multirow{2}{*}{ Economic (functional) } & - Need to control increasing public debt \\
& - Need for economic accountability concerning public financial resources \\
& - Shift towards effectiveness and efficiency of the public sector \\
& - Availability of new information system technologies \\
& - Public sector reforms requiring the implementation of PMSs in the public sector (coercive pressure) \\
& - Enlargement of the stakeholders to be considered in public sector action and accountability (normative pressure in relation to the \\
& professionalization of the public sector) \\
& - European integration (coercive pressure) \\
& - Diffusion of NPM logics (mimetic processes) \\
& - Managerialism, managers' responsibility and accountability \\
Human (individual) & Management personal skills development
\end{tabular}
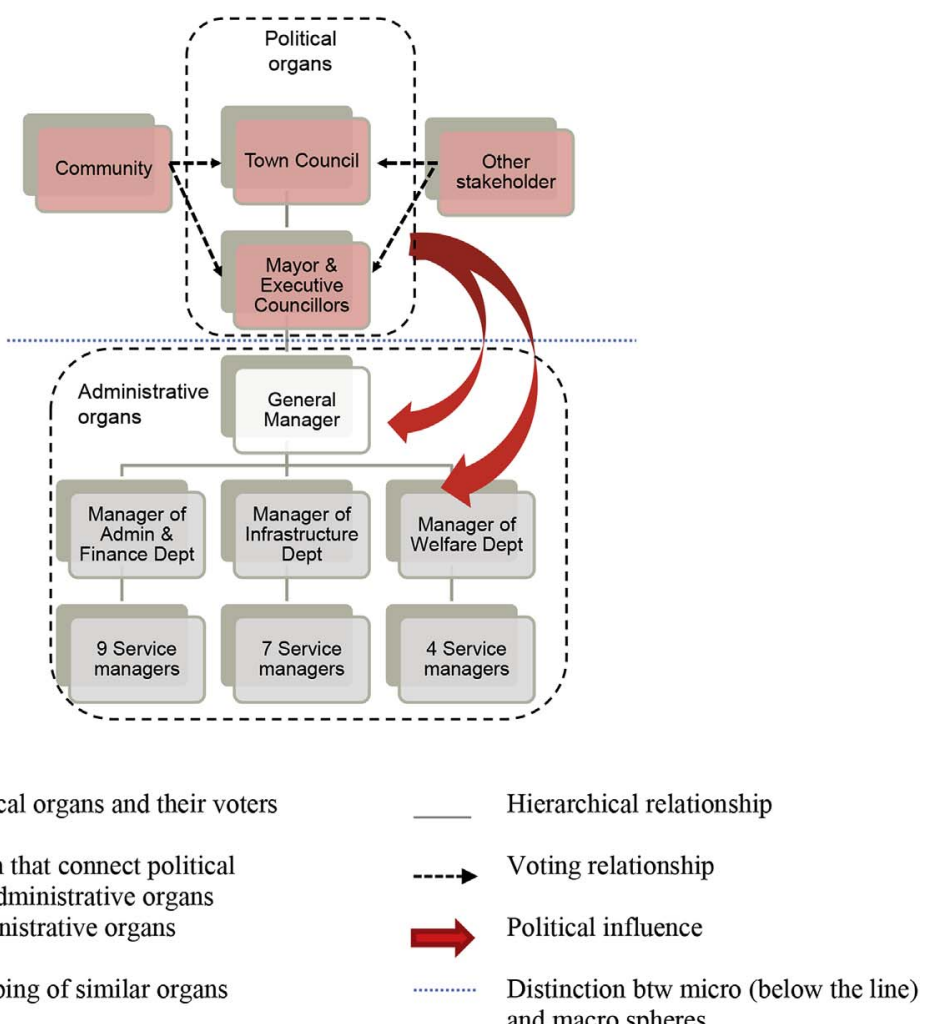

Organ that connect political and administrative organs Administrative organs

Grouping of similar organs and macro spheres

Fig. 3. Case study: organizational chart.

phase (2009) required that once identified, these objectives needed to be reclassified under four perspectives of the BSC (community/ stakeholders, financial, internal processes, learning and growth). For instance, management classified the following objectives under the community perspective: "put citizens first; make services accessible; improve security and services' standards" (developed from direct participation in a managers' roundtable).

Indeed, it was clear from the discussions that the management had different perceptions about the key objectives and even about the main stakeholders. The ambiguity (lack of clarity) of the resulting mayor's strategic priorities (e.g. "lifestyle in town") and organizational objectives (e.g. "put citizens first") hampered the entire process. A dotted line between internal agents and external structures has been traced in Fig. 3: while these spheres might appear as distinct, they are not mutually exclusive and the management (internal agents) tended to flexibly mobilize across that distinction the external stakeholders, bringing them farer or closer to their own considerations.

Moreover, when asked during the interviews about the opportunity of linking financial and non-financial aspects of the four BSC perspectives, all the departmental managers and service managers agreed that they preferred to rely on the existing bureaucratic mechanism of the financial budget, and the political relationship with the executive councillors, because the exact identification of the objectives and/or their linkages was seen as not feasible.

The setting of performance targets was even more problematic as the enlarged steering group had not clearly specified the 
organizational objectives and strategies - they were too broad and lacked cohesion across the four perspectives of the typical BSC. Secondly, for many potential measures there was no available data, information or useful records (e.g. how to measure "lifestyle in town" or "put the citizen first"). These aspects undermined the possibility of identifying a clear BSC, because this depends on the "causal" linkages among the four perspectives and the measurement of indicators typical of each perspective (Kaplan \& Norton, 1992).

The general manager reflected that the alignment phase of the project in 2010 resulted in a complete misalignment (McLaren et al., 2016; Sulaiman \& Mitchell, 2005). He suggested that this was due to an explicit choice by the managers to "play around with" the definition of the strategic goals, without making them coherent with stakeholder (community) needs. This view was also confirmed by the welfare department manager:

"We are aware that we should consider the stakeholders' view in the definition of the strategy, but we have never done it formally, neither we have defined whom are they and how we can involve them in the strategic planning" (manager of the welfare department).

In the last phase (2010), service managers also highlighted the difficulty of accepting the new mechanism and logic of the BSC from the very beginning of the project. The entire management believed the tool was a poor fit for the public sector, where priorities were established through changing political mechanisms.

"We have a climate of prolonged uncertainty, which is for colleagues and for sessional staff. On one hand, this is demotivating and, on the other hand, this carves [out] from the inside the meaning of any planning" (service manager of the cultural activities).

We then tried to disentangle the specific reasons and/or missed rationales of these results by examining Granlund's (2001) forces for the case study under analysis. Given these considerations of the three phases, we explore the implementation phase in depth because this most effectively highlights the rationale and reaction of management to the PMS change.

\subsection{Economic forces}

In this section, we analyze the interplay of economic forces in terms of resource allocation, information systems and mechanisms of reward. During the implementation phase, and particularly in the definition of the BSC's strategic objectives, there was intense debate about how financial resources would be allocated among the departments and services. The allocation was traditionally made through the financial budget. The latter was discussed and approved within the town council, according to a forecast of the amount distributed by the government to the local level and/or collected through local forms of taxation. This allocation was also subject to the mayor's political program and the spending requests or proposals of each departmental and service manager. But the entire management's main focus was on the financial budget and the specific budget allocation they were entitled to manage.

In terms of financial matters, each service (under a defined department) identified itself as the recorder of the financial budget it was entitled to manage:

"The final recording of the objectives is against the PEG" (service manager of the urban planning).

"The final scope is to align with the 'accounting for the mandates', in other words, the PEG" (service manager of the cultural activities)

"The allocation of the resources within this administration, among the departments and services, is a political choice [...] that is mirrored in the PEG" (administration and finance manager).

From this point of view, the first concern of each manager was the amount of his/her allocation in the financial budget. Again, this shows enhanced accountability towards the political organs, which ultimately identify and coordinate the amount of resources to be allocated. Therefore, the possibility of satisfying a number of stakeholders (community) became a secondary aspect, and something of an irrelevance for the allocation of funding.

That result denied a fundamental aspect of the BSC implementation: the interrelation between the four perspectives, where the financial performance should be considered the result of the value created for the stakeholders/community, the efficiency gained in internal processes, and the improvement of the learning and growth aspect of the organization (Kaplan \& Norton, 1996). In this case, the stakeholders/community are never explicitly identified with the "final users" of the services provided, whereas the town council members, who finally decide the allocation of the financial resources, were committed to the idea that the budget should serve their purposes, with limited consideration of other stakeholders.

The implementation phase of the BSC implied an effort towards the integration of the information system, in order to give transparency and access to cross-organizational information. However, the results suggested that the most important and reliable source of information was the traditional financial report, which provided a basis for future financial resource allocations:

"If we don't receive any input, we follow the historical processes and allocations" (manager of the welfare department).

The existing information system was partly formal, with local specificities, and many service and departmental managers stressed its inadequacy (see also Granlund, 2001). They expected the administrative and financial department to make an effort towards the change, but they were not willing to share their own information, or make it readable and understandable in an integrated system. In some cases, the respondents felt that the information requested was not relevant to the effective activity of their department or service, but was required to fulfil the interest of third parties, who only marginally understood their actual needs. This feeling 
undermined the perceived usefulness of a formal integrated system, constraining it to "secondary" or "non-essential" data production:

"We do not have an integrated informative system [...] From my point of view, here, everyone has his/her own informative system" (manager of the infrastructure department).

"From an information point of view, there isn't any link, I mean any link [...] And there is not an integrated system, so except for the accounting recording, we have our own informative system of staff management" (service manager of the theatrical activities).

"The information produced should be reflective of the work of the service or department. Now, you understand that I cannot produce the information on 'how many times we have blown our nose', if that information is relevant only for the interest of this one or that one" (manager of the infrastructure department).

However, the relevant information (i.e. "reflective of the work of the service or department") is communicated through informal meetings, phone calls and conversations with the council members:

"Some types of information are linked to the technical knowledge of the service managers, but the strategies are defined by the town council. For the strategies concerning my service, the council member of reference might ignore some aspects and I give input or I formulate proposals for him to bring to the mayor, so I can say there is a reciprocal collaboration [...] Even the choice of which services to cut within my unit is commonly agreed with the council member of reference and the mayor [...] I would say this daily dialogue is a gearwheel which moves quickly" (service manager of the cultural activities).

A further element of debate in 2009 (implementation phase) was the alignment between the BSC and the reward system within the local authority: the resulting BSC could not be linked to any possible reward system. This was a consequence of internal resistance towards being evaluated according to what managers perceived as ever-changing objectives and targets. This was also the result of the interpretation of the BSC as a tool to fulfil the needs of the preparation of the responsibility center budget (PEG) (somehow useful in supporting the status quo and the current operations) but not as a means of evaluation.

"I'm against an internal system of individual performance assessment. To evaluate, you need to make clear contents and responsibilities, but here the contents are always changing" (manager of the welfare department).

"I mean the BSC should give an overview of different separated activities of this complex administration and how they fluidly interconnect. In so doing, it eases the preparation of the PEG" (manager of the infrastructure department).

A source of resistance stemmed from a culture of broad-based rewards (unrelated to performance of the organization as a whole) that did not take into consideration the competencies and expertise of the managers or the results achieved.

"Although some managers are against it [a productivity bonus equally distributed to everyone], the majority of employees are fine with that. As a matter of fact, it would be very hard to change this expectation in the short run" (administration and finance manager).

During the planned alignment phase, the general manager attempted to involve departmental and service managers in the collection of performance-related information to be connected with the strategic objectives. However, this initiative was dismissed or ignored: reports arrived late and incomplete, signalling an ultimate lack of engagement with the BSC project. Overall, the attempt in the last phase of the project to align the internal processes with the BSC was not made possible, and the existing mechanisms of resource allocation through the yearly financial budget and PEG, as well as the information and reward systems, remained unaltered.

\subsection{Institutional forces}

Following Granlund (2001, p. 155), this section analyzes the institutional forces in terms of organizational culture and routines. We highlight these elements looking at the formal and informal relationships of the actors within the given organizational chart.

From an organizational point of view, the implementation phase of the project showed how the complex entrenched network of accountabilities between the political organs (mayor, executive councillors and town council) and the organization (general manager, departments and services) emerged to be stronger than the internal hierarchy. The management of the relationships with the political organs of the local authority clearly an element of continuity with the public sector before the reform and the attempt to implement the BSC. Moreover, our analysis highlighted that the network of accountabilities with the political organs (instead of the internal hierarchy towards the general manager) reflected the effective system of authorization and mobilization of resources allocated, perpetuating the reproduction of the social order (Macintosh \& Scapens, 1990).

The managers' perceptions collected during the implementation phase were influenced by the specific activities of their own departments and their relationships with the mayor or the executive councillors:

"In our reality the objectives are different, they are a lot and, above all, they are always changing, because the political component is a thing that the private sector does not have. In other words, between the objectives of the mayor, when he takes office, and what we have to do, there is a set of objectives that emerge day by day" (manager of the infrastructures department).

The interviews highlighted some criticalities, namely political dynamics and internal division. As the main accountability relationship of the organization was oriented towards the executive councillors and the mayor, the identification of services, strategies, day-by-day activities and objectives was a matter of political bargaining. Moreover, each organizational unit emerged as a stand- 
alone one, rejecting any form of collaboration likely to affect its network boundaries.

In this situation, the main intention of the departmental managers was to avoid any crossing over of their goals with those of the other departmental and/or service managers:

"For specific situations I talk with my council member of reference and the other service managers of the department contact me [...] All the (political) mandate objectives are shared with the other service managers [...] There is a lot of oral information [...] but the general impression is a resistance to meet/cross other functions in other organizational units" (service manager of the youth and sport activities).

"The administrative style has certainly been pressured to change, however, even if you want to implement changes, who has been employed for 10 years or more and is used to work in a certain way, will never change if suddenly he is required to turn of $90^{\circ}$ his behavior" (manager of the infrastructures department).

These quotations depict some further aspects of the organization. For instance, the perception of an established organizational reality that could not change, and the high attention to the operative aspects of administrative functioning. Departmental and service managers were not concerned about a strategic view of the organization; they were instead more interested to know how any eventual change would affect their operative work and coordination.

These results help us to understand the ways certain modes of behavior become institutionalized and reproduced in daily practice (Giddens, 1979, 1984; Macintosh \& Scapens, 1990). Furthermore, the evidence suggests that people fundamentally did not engage with the required change because they felt comfortable with their former routines (Erikson, 1963; Giddens, 1979; Granlund, 2001), which in turn complied with a set of values and norms embedded in the pre-reformed administration.

As a result, the departmental management relied on two mechanisms to facilitate coordination. The first was setting up a personal network of relationships with their service managers and employees (bottom up), and the second was frequent negotiation with executive councillors to gain their attention and identify those factors that were influencing the council members' decision making (top down). These mechanisms emerged through the interviews of the implementation phase, but it was clear that they pre-existed the BSC project. The manager of the welfare department described those two shared mechanisms as follows:

"I believe I have a sufficient recognition of my authority from my service managers, thus on the day-by-day activity, I rely on their autonomy, because they are following stabilized administrative procedures" (manager of the welfare department).

"I take the decisions on the basis of the meetings I have with the executive councillors because no one will tell you the source of information, where the information is located, who collect the data, etc. [...] Then, each executive councillor has his own attitude, his own perspective and way to face the problems" (manager of the welfare department).

The internal networks and meetings with the town council led to strong personal relationships which, in turn, led to the creation of so-called "autonomous worlds" within the organization. This resulted in managers developing a sphere of personal influence, and created resistance to greater transparency.

The managers' comments revealed that the means of human agency mainly consisted in "lobbying" the political organs of the local government. This shows that the "lobbying" interest resided in the individual attitude but, above all, in the desire to maintain the historical allocation mechanisms and the institutionalized fragmentation of the information system (economic factors) around the knowledge retained in each service or department (Granlund, 2001). Therefore, institutionalization of rules through actions depended on the interconnection of structures with the agency of actors. The latter is central to understanding the stability of the existing accounting practices, and the interplay between the institutions and the micro-practices activated by the actors involved in the PMS implementation.

\subsection{Individual/human factors}

Granlund (2001) emphasized the importance of human factors in understanding the ultimate reasons for finalization of a project.

In summarizing the forces affecting the PMS change in his case study, Granlund (2001) links the individual/human factor to the categories of economic and institutional factors, through the attitude and reaction of the organization's staff to "an economic explanation in terms of "time for money", but also to an institutional explanation in terms of routinization" (p. 153).

In our case study, it could be argued that the historical financial allocation of the resources and the current jeopardized information system have enhanced existing informal accountabilities between political and managerial organs of the local authority, but human factors have clearly and purposely reinforced these dynamics, as indicated in the following quotes:

"Two of the few integral elements of the local authority, since centuries ago, are the town council and the mayor with the executive councillors. I don't say this because I am a historian, but because it is a fundamental issue: we pertain and we are the product of that history" (manager of the infrastructures department, design phase).

"Personally, I love the hierarchy, because it introduces objectivity in our actions, but it is obvious that even in the hierarchy as an efficient form of organization, there are free spaces for the exercise of 'hidden pressures' and these pressures are lethal, as they can create a lot of organizational pathologies, but they are at the same time, unavoidable" (manager of the welfare department, design phase).

"You talk about the BSC and I talk about the PEG, in any case, I see them as tools that should serve the mayor's strategy. My actual 
concern is that we can make all the clothes that we want, but if there is no one who actually wears the clothes, they will become useless. In our case, the mayor gives us the main strategic direction, but it is upon us their operative translation. For this translation, you cannot count on a tool or on a functional office, such as a planning and control office, because they are not those who wear the clothes. Therefore, we rely on collegial moments and, above all, on the drift effect coming from our own negotiations with our executive councillor of reference who is clearly part of the political organ." (manager of the infrastructure department, implementation phase).

Whereas the first quote outlines the reliance of the managers on the embedded routines, without any desire or explicit need to redesign them towards a possible change, the second quote highlights the unavoidability of the political pressures within the given organization. Both these considerations, highlighted in the design phase, imply that whatever project or required change is misaligned with the mentioned routines and practices, it is automatically dismissed (i.e. the management does not engage with it). The third quote from the implementation phase shows values and culture ("we rely on collegial moments") entrenched in the Italian public sector, and the willingness of every manager in the organization to use political mechanisms (connections with the executive councillors) to fill the gap between the intended strategy (here referred to as the mayor's program instead of the general director's objectives) and their day-to-day activity.

The third quote also introduces an indirect lack of management support for further managerial initiatives (such as the BSC or the implementation of a planning and control office). This is expressed through the difficulty of finding an actual role/figure within the current administration to "wear the clothes" made by the organization, and therefore that moment is recovered through collegial decision making.

Thus stability emerged due to conscious reflections and decisions by managers to engage or not in the changes, as the following quotes make explicit:

"I heard about BSC and I read a presentation, and I am interested in knowing more, and assessing the possibility for the introduction, and how to change the existing control systems" (administration and finance manager, design phase)

"The BSC looks interesting and has potential. However, in my department I will keep the existing planning and controlling systems, which come from internal sources, and I don't think I need any other external support" (manager of the infrastructure department, implementation phase).

In both quotes, the managers share the view that the BSC can potentially improve control, but this is consciously dismissed in the second quote. The level of engagement implies a reflexivity, which leads to a conscious choice about BSC mobilization and effective use, and finally indicates the managerial behavior.

Deep-seated norms and values regarding the way human resources were allocated and managed also appeared to support a position of stability and to inhibit the introduction of the BSC:

"In the public administration, even if you have people who don't match with the organizational profiles [nor] with the organizational needs, you must keep them! And you should understand where placing him/her with the maximum advantage for his/her political allies and for your organization. [...] I think that the problem of human resources is also a problem of efficiency, but we don't really want to touch the relevant things" (service manager of planning and control, implementation phase).

"Then, matters regarding appointments, tasks, responsibilities are followed on the political ground, it is a political occurrence. This is the situation!" (service manager of human resources, implementation phase).

In particular, we identify a number of criticalities affecting the human resources in a public-sector organization, namely, lack of managerial skills (they were not required by law before 2009), difficulties matching organizational profiles and competences, and political interference in the mechanisms of appointments and assignment of tasks. As formerly stated, even if the above elements emerged through the interviews during the implementation phase, they pre-existed the BSC project and historically characterized the case study.

\section{Discussion}

Our case interpretation brings together the key themes around change and stability in public authorities identified by Granlund (2001). In Table 4, we consider the contrasting forces of stability in the case organization, clarifying the substantial complexities of an Italian local authority. These complexities (for instance the involvement of political organs, the attention towards resource allocation instead of stakeholders, and the importance of interpersonal relationships and networks) led to the early disengagement with the implementation of the BSC. The analysis suggested by Granlund (2001), however, further enlightens us about how the agents' reflexivity and engagement with the BSC was reflected in their micro-practices.

More specifically, the implementation of a PMS was supported by the rational, efficient argument of the last statutory requirements (following the NPM paradigm) of public sector reforms from the 1990s onwards (Arnaboldi et al., 2016; Dunleavy \& Hood, 1994; Granlund \& Lukka, 1998; Hood, 1991; Lapsley, 2008). The general manager of the case organization embraced these macro environment pressures. However, the implementation of the BSC tended to avoid considering the political bargaining and embedded routines and values (e.g. divisionalization, autonomy of the organizational units, and prevalence of the operative aspects) of the local authority.

Following Granlund's (2001) systematization of the forces affecting the development of a new system (or intentions - p. 153), 
Table 4

Forces influencing the stability.

\begin{tabular}{|c|c|}
\hline Factors & Stability \\
\hline Economic (functional) & $\begin{array}{l}\text { - Resource allocation within the organization is not decided autonomously but through the political organs } \\
\text { - Tendency to follow historical criteria of allocation } \\
\text { - Reliance on the financial budget and the PEG } \\
\text { - Established broad-based rewards } \\
\text { - Lack of an integrated information system }\end{array}$ \\
\hline Institutional & $\begin{array}{l}\text { - High level of divisionalization and autonomy of each organizational unit }{ }^{\mathrm{a}} \\
\text { - Lack of strategic view, as the strategic objectives depend on a contingent negotiation between departmental, service managers and } \\
\text { political organs } \\
\text { - Specific attention to the operative functioning } \\
\text { - Explicit reference to historical established values in the public sector } \\
\text { - Widespread propensity towards the creation of interpersonal relationships and networks (informal meetings - potential link with } \\
\text { human factor) }\end{array}$ \\
\hline Human (individual) & $\begin{array}{l}\text { - Scarce managerial skills among the management } \\
\text { - Fear about sharing information and collaboration } \\
\text { - Political influence over managers' autonomy } \\
\text { - Difficulties to change current human resources policies }{ }^{\mathrm{b}}\end{array}$ \\
\hline
\end{tabular}

${ }^{\text {a }}$ Normative pressure in relation to the historical professionalization of the public sector.

${ }^{\mathrm{b}}$ Partly normative pressure in relation to the historical professionalization of the public sector and partly historical mimetic processes.

Table 4 refers to the micro environment, and shows that stability is mainly supported by normative pressures and isomorphic processes embedded in the organization. The behavior and perceptions, shown in the institutional and human/individual factors in Table 4, support the idea that normative pressures, having their roots in public sector history, flag a common understanding or framing of public sector functioning among the managerial levels of the local authority. These common roots and understanding, which we might define as administrative culture, influence the "agency" of individuals in terms of the adoption of the BSC. Management's lack of engagement with the BSC project highlighted the stability of the existing mechanisms and practices in several areas. These included resource allocations; the information system and incentive system (economic factors); the preference for informal and localized systems of interpersonal relationships as decision making and accountability processes (institutional factors); and outdated human resources policies that affected, in turn, the perception of the general manager's proactivity and the usefulness of the new PMS (individual factors). All managers favored the stability of former practices and mechanisms.

Granlund's (2001) three-factor classification is a valuable framework to identify and contrast potential influences on the success or failure of the BSC project. In this study, micro-level analysis revealed how the ways of thinking and behaviors of the individual managers - the human factor - were influenced by, and influenced the perception of, the importance and relevance of the economic and institutional factors in the BSC project.

The analysis of the decree laws relating to the reforms shows the emergence of a discourse of economic accountability, and increasing calls for the implementation of private-sector managerial tools at the macro level to enhance efficiency, effectiveness and public accountability. In this sense, there is a discrepancy between the legal prescriptions and the actual organizational functioning of the Italian public sector. The reforms under NPM enhanced the role of the general manager as a leader promoting changes like the implementation of a new PMS, without considering that the functioning of any public administration is not strictly hierarchical, but collegial, where the role of department and service managers is fundamental. Unfortunately, in the managers' perception, the abovementioned NPM discourses have become a common driver of the political rationale only in the last two decades in Italy, whereas the Italian public sector and its practices are centuries old. Therefore, there seems to be an incompatibility between the change implied by the BSC, driven by coercive (regulatory) pressures and recent normative and mimetic NPM processes (e.g. diffusion of NPM; European integration; public sector reforms and increased professionalization of public managers), and the institutionalized mechanisms of operation and legitimation (Giddens, 1979) entrenched in the "culture" of the public sector.

Our results reveal that the actual functioning of the micro level resided in the lobbying of political organs, the delineation of personal networks, and the retention of asymmetrical information, which implies proactive and expressed actions of the human factor (managers) within the case organization. The interviews also suggested the presence of allocation mechanisms that were far from the principles of effectiveness and efficiency proclaimed by the macro-level reforms, but supported the existing coping mechanisms of department and service managers.

\section{Conclusion}

This study responds to the call of Bracci et al. (2017), Cooper et al. (2017), Järvenpää and Länsiluoto (2016) to examine the role of individuals and/or organizational groups in explaining accounting change. It embraces the possibility of the co-existence of stability and change in organizations (Aroles \& McLean, 2016), supporting Granlund (2001), and Scapens and Macintosh's (1996) observation that management accounting change depends on a deep understanding of the dynamics, rationale and agency involved in the maintenance of a social order. This is consistent with Englund et al.'s (2011) and Stones' (2005) work, which notes the importance of considering human agency in relation to both accounting stability and change. This provides a clearer understanding of the relationships between external structures and organizational agents. Our results emphasize the role of the human factor (individuals) 
with respect to institutional and economic forces, and establishes the role of human agency as strictly interconnected with the normative aspects of the institutional category. We shed light on the actions of organizational actors to maintain their interpretative schemas amid the inherent reproduction of social routines, for reasons rooted in the history of public administration. The analysis and conclusions of our 2008-2010 study have also been informed by, and benefited from, recent work in the field (noted above) and a closer look at the "management" side of the performance management in the public sector (Arnaboldi et al., 2015).

This study makes a number of contributions. First, we offer an interpretation of Granlund's (2001) framework through our operationalization of the economic, institutional and individual (human) forces that affect change or stability. We also use this systematization to examine both the macro environment of external pressures, and the micro environment of the case organization.

Second, we introduce a historical recounting and a longitudinal evaluation of the interrelations between these forces in a publicsector context, showing how they interacted in the trend of Italian NPM reforms, and in changing or maintaining the stability in the case analyzed. The analysis reveals that Granlund's (2001) systematization of the factors of stability is not fully applicable to the public-sector. We therefore elaborate on a broader idea of "administrative culture" and following "agency", which encompasses both political and informal networks. Extending Granlund's (2001) study, we show that explicitly political mechanisms and interpersonal networking affected the economic (allocation of resources) and institutional factors, and the spheres of individual influence in the organization. This is not only valuable evidence on how stability is expressed (i.e. Scapens \& Roberts, 1993 and Malmi, 1997), but it demonstrates there was a clear manipulation of the inputs, the process of implementation, and the intended outcomes that was completely disengaged from the new mandated PMS.

Third, we provide a specific account of macro-level pressures (reforms) and micro-level (case) practices, actions and behavior, proposing a continuous dialectic between the two levels of analysis, to address the "taken-for-grantedness" limitation of the institutional theory, and offer a more extensive mobilization of Giddens (1979) and Granlund's (2001) "ontological security" argument for "resistance to change" (see also Englund et al., 2011). This demonstrates that underestimating the role of agency, established practices and entrenched cultural values at the micro level is likely to affect the success of macro level NPM projects. A coercive (regulatory) change may not be effective, and it risks being adopted only superficially at the micro level if the normative historical pressures are not sufficiently engaged. We provide evidence that the actions of organizational actors reinforced the economic and institutional factors, which could never be completely separated from the human factor (Macintosh \& Scapens, 1990). Although Granlund's (2001) systematization allows a clear separation of the three factors at the macro-level analysis, our findings show the relevance of identifying their interconnections (and not complete separability) at the micro level.

We suggest greater reflection is needed regarding the conceptual integration of the PMS with both the external and internal organizational environment in which it is implemented. Future research should further seek to deepen our understanding of the historical trends of public administration in explaining and justifying the effects of shared values and beliefs. Finally, a thorough analysis of the link between the above-mentioned economic, institutional and human factors would elucidate the unity between the social and technical dimensions of PMSs in relation to the embedded agency of individuals.

\section{Acknowledgements}

This research did not receive any specific grant from funding agencies in the public, commercial or not-for-profit sector.

\section{References}

Abernathy, W. J., Clark, K. B., \& Kantrow, A. M. (1981). The new industrial competition. Harvard Business Review, 59(1), 56-68.

Archibugi, D., \& Michie, J. (Eds.). (1997). Technology, globalisation and economic performance. New York: Cambridge University press.

Arnaboldi, M., Lapsley, I., \& Dal Molin, M. (2016). Modernizing public services: Subtle interplays of politics and management. Journal of Accounting and Organizational Change, 12(4), 547-567.

Arnaboldi, M., Lapsley, I., \& Steccolini, I. (2015). Performance management in the public sector: The ultimate challenge. Financial Accountability and Management, 31(1), 1-22.

Aroles, J., \& McLean, C. (2016). Rethinking stability and change in the study of organizational routines: Difference and repetition in a newspaper-printing factory. Organization Science, 27(3), 535-550. http://doi.org/10.1287/orsc.2015.1035.

Barley, S. R., \& Tolbert, P. S. (1997). Institutionalization and structuration: Studying the links between action and institution. Organization Studies, $18(1)$, 93-117.

Bassanini, F. (2000). Vent'anni di riforme del sistema amministrativo italiano (1990-2010). Rassegna Astrid, 109(4).

Beaubien, L. (2012). Technology, change, and management control: A temporal perspective. Accounting, Auditing and Accountability Journal, $26(1), 48-74$.

Boudreau, M. C., \& Robey, D. (2005). Enacting integrated information technology: A human agency perspective. Organization Science, 16(1), 3-18.

Bracci, E., Humphrey, C., Moll, J., \& Steccolini, I. (2015). Public sector accounting, accountability and austerity: More than balancing the books? Accounting, Auditing and Accountability Journal, 28(6), 878-908.

Bracci, E., Maran, L., \& Inglis, R. (2017). Examining the process of performance measurement system design and implementation in two Italian public service. Financial Accountability and Management, 33(4), 406-421.

Broadbent, J. (1992). Change in organizations: A case study of the use of accounting information in the NHS. The British Accounting Review, $24(3), 343-367$.

Broadbent, J., \& Guthrie, J. (2008). Public sector to public services: 20 years of "contextual" accounting research. Accounting, Auditing and Accountability Journal, 21(2), $129-169$.

Burns, J., \& Scapens, R. W. (2000). Conceptualizing management accounting change: An institutional framework. Management Accounting Research, 11(1), 3-25.

Carlin, T., \& Guthrie, J. (2003). Accrual output based budgeting systems in Australia. The rhetoric-reality gap. Public Management Review, 5(2), 145-162.

Cassese, S. (2010). Il diritto amministrativo. Storia e prospettive. Milano: Giuffre.

Cassese, S., \& Melis, G. (1990). Lo sviluppo dell'amministrazione italiana (1880-1920). Rivista Trimestrale di Diritto Pubblico, 2 (3), $333-342$.

Chandury, M., \& Lee, C. (1997). Functional forms of stock return model. Some international evidence. Quarterly Review of Economics and Finance, 37(1), 151-183.

Chan, K. C., Gup, B. E., \& Pan, M.-S. (1997). International stock market efficiency and integration: A study of eighteen nations. Journal of Business, Finance and Accountability, 24(6), 803-813.

Christensen, T., \& Lægreid, P. (2007). The whole-of-government approach to public sector reform. Public Administration Review, 67(6), 1059-1066.

Cloutier, C., \& Langley, A. (2013). The logic of institutional logics - insights from French pragmatist sociology. Journal of Management Inquiry, 22(4), 360-380. 
Coad, A. F., \& Cullen, J. (2006). Inter-organisational cost management: Towards an evolutionary perspective. Management Accounting Research, 17(4), 342-369.

Cooper, D. J., Ezzamel, M., \& Qu, S. Q. (2017). Popularizing a management accounting idea: The case of the balanced scorecard. Contemporary Accounting Research, 34(2), 991-1025.

Cooper, R., \& Kaplan, R. S. (1988). Measure costs right: Make the right decisians. Harvard Business Review, (September-October), 96-103.

Creed, W. E. D., Scully, M. A., \& Austin, J. R. (2002). Clothes make the person? The tailoring of legitimating accounts and the social construction of identity. Organization Science, 13(5), 475-496.

Dacin, M. A., Goodstein, J., \& Scott, W. R. (2002). Institutional theory and institutional change: Introduction to the special research forum. Academy of Management Journal, 45(1), 45-57.

Dawson, P. (1996). Organizational change: A processual approach. London: Paul Chapman Publishing.

Dechow, N., \& Mouritsen, J. (2005). Enterprise resource planning systems, management control and the quest for integration. Accounting, Organizations and Society, 30(7), 691-733.

Di Maggio, P., \& Powell, W. (1983). The iron cage revisited: Institutional isomorphism and collective rationality in organizational fields. American Sociological Review, 48(2), 147-160.

Dillard, J., Rigsby, J. T., \& Goodman, C. (2004). The marking and remarking of organizational context. Accounting, Auditing and Accountability Journal, 17(4), 506-542.

Dunleavy, P., \& Hood, C. (1994). From old public administration to new public management. Public Money and Management, 14(3), 9-16.

Edwards, T. (2006). Book review: Developments toward the operationalization of structuration theory. Organization, 13(6), 911-913.

Emirbayer, M., \& Mische, A. (1998). What is agency? American Journal of Sociology, 103(4), 962-1023.

English, L. M., \& Skellern, M. (2005). Public-private partnerships and public sector management reform: A comparative perspective. Journal of Public Policy, 1(1-2), $1-21$.

Englund, H., \& Gerdin, J. (2008). Structuration theory and mediating concepts: Pitfalls and implications for management accounting research. Critical Perspectives on Accounting, 19(8), 1122-1134.

Englund, H., \& Gerdin, J. (2014). Structuration theory in accounting research: Applications and applicability. Critical Perspectives on Accounting, 25(2), 162-180.

Englund, H., Gerdin, J., \& Burns, J. (2011). 25 Years of Giddens in accounting research: Achievements, limitations and the future. Accounting, Organizations and Society, 36(8), 494-513.

Erikson, E. H. (1963). Childhood and society. New York: Norton.

Garud, R., Hardy, C., \& Maguire, S. (2007). Institutional entrepreneurship as embedded agency: An introduction to the special issue. Organization Studies, 28(7), 957-969.

Giannini, M. S. (1979). Rapporto sui principali problemi della amministrazione dello stato. Rome: Parliament Upper Chamber.

Giannino, O. (2011). Debito pubblico italiano: ammontare alle stelle nella seconda Repubblica. La Repubblica 14 September 2011.

Giddens, A. (1979). Central problems in social theory. London: Mac Millan.

Giddens, A. (1984). The constitution of society. Cambridge: Polity Press.

Giddens, A. (1987). Social Theory and modern sociology. Cambridge: Polity Press.

Ginsborg, P. (2001). Italy and its discontents: Family, civil society, state, 1980-2001. London: MacMillan, Palgrave.

Granlund, M. (2001). Towards explaining stability in and around management accounting systems. Management Accounting Research, 12(2), 141-166.

Granlund, M., \& Lukka, K. (1998). It's a small world of management accounting practices. Journal of Management Accounting Research, 10(2), 153-179.

Greenhalgh, T., \& Stones, R. (2010). Theorising big IT programmes in healthcare: Strong structuration theory meets actor-network theory. Social Science and Medicine, 70, 1285-1294.

Gurd, B. (2008). Structuration and middle-range theory - a case of accounting during organizational change from different theoretical perspectives. Critical Perspectives on Accounting, 19(4), 523-543.

Guthrie, J., Parker, L., \& English, L. M. (2003). A review of new public financial management change in Australia. Australian Accounting Review, 13(30), 3-9.

Hallet, T., \& Ventresca, M. J. (2006). Inhabited institutions: Social interactions and organizational forms in Gouldner's Patterns of Industrial Bureaucracy. Theory and Society, 35(2), 213-236.

Heclo, H. (2008). On thinking institutionally. Boulder, CO: Paradigm Publishers.

Ho, A. T. K. (2011). Performance-based budgeting in American Local Governments: It's more than a management tool. Public Administration Review, 71(3), 391-401.

Hood, C. (1991). A public management for all seasons? Public Administration, 69(1), 3-19.

Humphrey, C., \& Scapens, R. (1996). Theories and case studies of organizational accounting practices: Limitation or liberation? Accounting, Auditing and Accountability Journal, 9(4), 86-106.

Jack, L., \& Kholeif, A. (2008). Enterprise Resource Planning and a contest to limit the role of management accountants: A strong structuration perspective. Accounting Forum, 32(1), 30-45.

Järvenpää, M., \& Länsiluoto, A. (2016). Collective identity, institutional logic and environmental management accounting change. Journal of Accounting and Organizational Change, 12(2), 152-176.

Kaplan, R. S., \& Norton, D. P. (1992). The balanced scorecard measures that drive performance. Harvard Business Review, 70(1), 71-79.

Kaplan, R. S., \& Norton, D. P. (1996). Using he balanced scorecard as a strategic measurement system. Harvard Business Review, 74(1), 75-85.

Kaplan, R. S., \& Norton, D. P. (2001). The strategy-focused organization. Boston: Harvard Business School Press.

Lapsley, I. (2008). The NPM agenda: Back to the future. Financial Accountability and Management, 24(1), 77-96.

Lawrence, T., Suddaby, R., \& Leca, B. (2011). Institutional works: Refocusing institutional studies in organization. Journal of Management Inquiry, 20(1), 52-58.

Liguori, M., \& Steccolini, I. (2012). Accounting change: Explaining the outcomes, interpreting the process. Accounting, Auditing and Accountability Journal, 25(1), $27-70$.

Llewellyn, S., \& Tappin, E. (2003). Strategy in the public sector: Management in the wilderness. Journal of Management Studies, 40(4), 955-982.

Lounsbury, M. (2008). Institutional rationality and practice variation: New directions in the institutional analysis of practice. Accounting, Organizations and Society, 33(4), 349-361.

Lukka, K. (2007). Management accounting change and stability: Loosely coupled rules and routines in action. Management Accounting Research, 18(1), 76-101.

Macintosh, N. B., \& Scapens, R. W. (1990). Structuration theory in management accounting. Accounting, Organisations and Society, 15(5), 455-477.

Malmi, T. (1997). Towards explaining activity-based costing failure: Accounting and control in a decentralized organization. Management Accounting Research, 8(4), 459-480.

McLaren, J., Appleyard, T., \& Mitchell, F. (2016). The rise and fall of management accounting systems: A case study investigation of EVA. The British Accounting Review, 48(3), 341-358.

Nocera, S. (2001). La legge di riforma dei Servizi Sociali - Dal centralismo sociale al federalismo solidale. Educazione e Scuola, Archivio, 1-88.

Orlikowski, W. J. (2000). Using technology and constituting structures: A practice lens for studying technology in organizations. Organization Science, 11(4), 404-428.

O'Neill, H. M., Pouder, R. W., \& Buchholtz, A. H. (1998). Patterns in the diffusion of strategies across organizations: Insights from the innovation diffusion literature. Academy of Management Review, 23(1), 98-114.

Parker, J. (2006). Structuration's future? Journal of Critical Realism, 5(1), 122-138.

Pettigrew, A. M. (1997). What is a processual analysis? Scandinavian Journal of Management, 13(4), 337-348.

Pina, V., Torres, L., \& Yetano, A. (2009). Accrual accounting in EU local governments: One method, several approaches. European Accounting Review, 18(4), 765-807.

Pollitt, C., \& Bouckaert, G. (2004). Public management reform: A comparative analysis. Oxford: Oxford University Press.

Powell, W. W., \& Di Maggio, P. J. (1991). The new institutionalism in organizational analysis. Chicago: University of Chicago Press.

Quattrone, P., \& Hopper, T. (2005). A 'time-space odyssey': Management control systems in two multinational organisations. Accounting, Organizations and Society, 30(7), 735-764.

Qu, S. Q., \& Dumay, J. (2011). The qualitative research interview. Qualitative Research in Accounting and Management, 8(3), $238-264$. 
Randeraad, N. (1993). Authority in search of liberty: The prefects in liberal Italy. Amsterdam: Thesis Publishers.

Richard, N. (2004). Recovering from a tidal wave: New directions for performance management in New Zealand's public sector. Public Finance and Management, 4(3), $429-447$.

Ritchie, J., \& Spencer, L. (1994). Qualitative data analysis for applied policy research. In A. Bryman, \& R. G. Burgess (Eds.). Analysing qualitative data (pp. 173-194). New York: Taylor and Francis.

Ruffilli, R. (1989). Istituzioni Società Stato, Il ruolo delle istituzioni amministrative nella formazione dello Stato in Italia. Bologna: II Mulino.

Santoro, P. (2014). Deboli ma forti. Il pubblico impiego in Italia tra fedeltà politica e ammortizzatore sociale: Il pubblico impiego in Italia tra fedeltà politica e ammortizzatore sociale. Milano: FrancoAngeli.

Scapens, R. W. (1994). Never mind the gap: Towards an institutional perspective on management accounting practice. Management Accounting Research, 5(3-4), 301-321.

Scapens, R. W. (2006). Understanding management accounting practices: A personal journey. The British Accounting Review, 38(1), 1-30.

Scapens, R. W., \& Macintosh, N. B. (1996). Structure and agency in management accounting research: A response to Boland's interpretive act. Accounting, Organizations and Society, 21(7-8), 675-690.

Scapens, R. W., \& Roberts, J. (1993). Accounting and control: A case study of resistance to accounting change. Management Accounting Research, 4(4), 1-32.

Scott, W. R. (1995). Institutions and organizations. Thousand Oaks, CA: Sage.

Siti-Nabiha, A. K., \& Scapens, R. W. (2005). Stability and change: An institutionalist study of management accounting change. Accounting, Auditing and Accountability Journal, 18(1), 44-73.

Smith, D. M. (1997). Modern Italy: A political history. Chicago: University of Michigan Press.

van der Steen, M. (2009). Inertia and management accounting change: The role of ambiguity and contradiction between formal rules and routines. Accounting, Auditing and Accountability Journal, 22(5), 736-761.

Stones, R. (2005). Structuration theory. London: Palgrave.

Sulaiman, S., \& Mitchell, F. (2005). Utilizing a typology of management accounting change: An empirical analysis. Management Accounting Research, 16(4), 422-437.

Ter Bogt, H. J. (2008). Management accounting change and new public management in local government: A re-assessment of ambitions and results - an institutionalist approach to accounting change in the Dutch public sector. Financial Accountability and Management, 24(3), $209-241$.

Ventresca, M., \& Mohr, J. W. (2002). Archival research methods'. In J. A. C. Baum (Ed.). The Blackwell companion to organizations (pp. 805-828). Oxford, UK: Blackwell Publishers.

Whittington, R. (2011). The practice turn in organization research: Towards a disciplined transdisciplinarity. Accounting, Organizations and Society, 36(3), 183-186. 